\title{
Growing Up Multiply
}

British Women Write the Ampersand Experience

\author{
Isabel Carrera-Suárez and Carla Rodríguez-González
}

In 2016, Jackie Kay became Scots Makar, therefore receiving the ultimate honorary recognition from her native Scotland. She followed in the wake of Edwin Morgan and Liz Lochhead, two well established (white) Scottish writers from earlier generations. Three years later, in 2019, Bernardine Evaristo was awarded the Booker Prize for her novel Girl, Woman, Other, becoming the first black woman and the first black British author to win the most coveted literary prize in the United Kingdom. The fact that she shared it with Canadian icon Margaret Atwood did not detract from her historical achievement in reaching a zenith denied to shortlisted black writers in previous editions. Both Kay and Evaristo are in fact "mixed race", 2 but also identify as black through political choice and personal history. Both have spoken eloquently about their life stories in essays and interviews, and have translated the experience into autobiographically grounded texts, Kay in The Adoption Papers (1991) and Red Dust Road (2011), Evaristo in Lara (1997), although most of their writing relates only inspirationally to their personal lives. It is probable that in their shared period of activism in the 1980s they did not anticipate such individual success stories

1 Research for this chapter was supported by the Spanish R\&D Programme, project RTI2018097186-B-Ioo (Strangers \& Cosmopolitans) and RED2018-102678-T, financed by MCIU/AEI/ FEDER, EU; also by the R\&D Programme of Asturias, Research Group Intersections (IDI/ 2018/000167).

2 While very aware of the problematic politics of the term mixed race, most particularly of the fact that it seems to be endorsing the socially constructed and oppressive concept of "race", we follow Jayne O. Ifekwunigwe (2002, 2004) and Yasmin Alibhai-Brown (2001) in using the term, in preference to alternatives such as mixed, mixed-ethnic, dual/multiple heritage, $\mathrm{dual} /$ multiple ethnicity, on the one hand because it seems the preferred term by many selfidentified subjects, and on the other, for the purpose of specifying that being mixed race presumes differently racialised parentage, rather than simply different ethnic or geographical origins. We also omit the inverted commas around terms such as "race" and "mixed-race", "multi-racial" for conciseness. 
for the twenty-first century. These signal a change in the social perception of Britishness and of multiethnicity, although a perception still distant from the mirage of a post-race world announced by optimists when entering the new millennium.

In the pages that follow, through the liminal art forms of published life stories, we aim to explore the specific, contingent and evolving British environments that have resulted in the contemporary construction of multiple mixed-race subjectivities in Britain, and the role of early relational experiences in such constructions. We focus first on the growing visibility of these subjectivities from a quantitative perspective, discussing the data provided by official censuses as a measure of change and a political accomplishment of controversial interpretation. The intersectional variety comprised by the mixed-race category is next exemplified by means of high-impact social, artistic and media contributions, which introduce the analysis of significant literary works, particularly the life narratives collected in the volume Tangled Roots: True Life Stories about Mixed Race Britain (Massey 2015), and fictional accounts by Jackie Kay and Bernardine Evaristo. We explore how these portrayals of racialised childhood and adolescent experiences contribute to the on-going debate on issues of crucial importance such as authenticity, belonging and the affective estrangement of mixed-race young people in spaces that range from the public - schools, neighbourhoods - to the most intimate, the home.

In the United Kingdom, the first census to be conducted in the new century was also the first to include the category "Mixed/Multiple Ethnic", and therefore to produce official data on the subject. In this newly-offered opportunity for self-definition (with subcategories White and Black Caribbean, White and Asian, White and Black African, and Any other mixed background), 677,000 people identified as Mixed/Multiple, corresponding to $1.2 \%$ of the population. By the arrival of the next census, in 2011, the numbers and percentage had almost doubled (1.2 million, 2.2\%). Although figures and details are slightly blurred by different categories in Scotland and Northern Ireland vs. England and Wales and by the variability of self-identification, there is agreement that this is the fastest growing ethnic category in the United Kingdom. Research carried out by the ввс in the same year as the 2011 census, eliciting information about parents' ethnicity, suggested that the mixed race population of the United Kingdom might be twice the size of official figures, in fact already constituting the largest ethnic category after the majority "white" group. The 
design of a census is both a signifier of social change and a political action, as the comparison of national systems reveals. Even outside openly racist regimes such as South Africa under Apartheid (with its "coloured" category), new concepts can create a political storm. In the United States, for instance, where there is a strong history of hypodescent and monoracial identification (Daniel, Kina, Dariotis and Forjas 2014, 11), activism in favour of a multiracial category in the 1990 census met the opposition of monoracial groups, particularly African Americans, and resulted in the decision to allow the choice of several categories instead (Ifekwunigwe 2002, 323; Daniel, Kina, Dariotis and Fojas 2014, 16). Barack Obama, raised by his white mother and disputed biracial/black icon, famously checked only the "Black, African American or Negro" (sic) box in the 2010 census, an action coherent with his political positioning. The forthcoming UK census, to take place in 2021, may well confirm the progression of the mixed/multi ethnic category and perhaps offer further data about self-identification, as mixed heritage individuals decide whether to read themselves as monoracial/ethnic or mixed/multiple.

Not only quantitative matters have been in flux in the past two decades. British multi-ethnic, "non-white" individuals have also increasingly become prominent in the social, artistic and popular culture spheres, and gained unprecedented success and acceptance. World champion racer Lewis Hamilton and heptathlete Jessica Ennis-Hill, gold medallist who became the face of the 2012 London Olympics, as well as a number of musicians and media professionals, irrupted in their fields with the impact that Zadie Smith did in that of literature in the early years of this century. Their public recognition is well deserved, even if they found themselves used as unwilling proof of a post-race, smoothly multicultural Britain which was still removed from everyday realities. Despite such misgivings, the voices of mixed-race Britons have spoken and been listened to more intensely in the new century. A number of social, artistic and media interventions, participatory and historically oriented, have gained public attention. Grassroots action can be found in websites such as Mix-d (http://www.mix-d.org), or the older People in Harmony (http://www.pih.org. uk), founded in 1972 and Intermix (http://intermix.org.uk), in 1999. Mixed Race Faces (https://mixedracefaces.com), created by photographer Tenee Attoh as a tribute to her Dutch mother, who married a Ghanaian photographer in the 1950s and joined him in Ghana, showcases the portraits of "people with mixed heritage" taken by Attoh, together with the stories behind those faces. Social media have also connected and amplified voices in various ways: the Q\&A format of the "Mixed Girl Tag" is informative of the variety of adolescent perspectives and origins internationally, if also showing some reification 
of beauty myths. ${ }^{3}$ The ввс contributed to the historical contextualisation of British mixed-race stories with the successful ввС 2 documentary series Mixed Britannia (2011), advertised as "the previously untold history of Britain's mixed race community and the many love stories that created it", led by presenter and journalist George Alagiah. The common denominator of these sites and initiatives is the unearthing of hidden stories of personal relationships and the great intersectional variety that they communicate, a characteristic they share with the printed stories we are about to discuss. Together, they may enable a better understanding of what Jayne Ifekwunigwe denominates the "perhaps utopian" model of the "ampersand", an inclusive paradigm for belonging which is not predominantly racialised $(2002,328)$, although acknowledging the impact of white exclusionary practices in the production of local and transnational identities. The model stresses how "generation, locality, gender, visual proximity to popular perceptions of 'whiteness'" all determine racial or ethnic identification (329).

\section{$3 \quad$ Writing Lives: Tangled Roots and Stories of Becoming}

In parallel with these collective voices, literary and critical writing have contributed towards a better understanding and conceptualising of the (British) mixed-race experience, foregrounding its complexity, its historical, geographical and cultural specificity and its intersectionality (Alibhai-Brown 2001; Ifekwunigwe 2004; Song 2010; Caballero and Aspinall 2018; and an important section of Hirsch 2018). In 2015, Katy Massey edited the collection Tangled Roots: True Life Stories about Mixed Race Britain, a creative-critical volume which includes 32 contributions, the first five by established writers Diana Evans, Bernardine Evaristo, Hannah Lowe, Sarfraz Manzoor and Charlotte Williams. These, and the 27 pieces that follow, are life narratives that move between the forms of the essay, the short story and autobiography. Like the visual project Mixed Race Faces, the volume offers individualised—in this case verbal-portraits which exemplify the broad range of geographical origins, ethnic combinations and shades of colour that "Mixed Britain" encompasses, and offers nuanced meditations on heritage, Britishness and interracial relations as they shape identities in adolescence and early adulthood.

3 We are grateful to Sofaya Hussein, our student in the Erasmus Mundus ma in Women's and Gender Studies (GEMMA) in Oviedo, for allowing us insight into the content and significance of this tag, which she analysed in her MA dissertation. 
Massey's introduction to Tangled Roots justifies the need for such a volume in 2015 , a time when overt racism is generally unacceptable and the former views of mixed-race children as pathological and marginal have subsided. Despite the liberating effect of 1980 os identity politics, despite the current generation being "the most relaxed of any previous generations about 'race' and inter-race relationships" (British Future report The Melting Pot Generation 2011, quoted in Massey 2015, 10), Massey argues the need for further investigative work, going beyond celebratory or social-science led "problem" approaches, to unearth how this mixed Britannia came to be. Her collective volume is posed as an intervention, an enquiry into the how and the why, and at what cost, Britishness has ceased to be the preserve of those not "raced" (15). With its claim to present "true" life stories, Tangled Roots can be read as an idiosyncratic map of origins, childhood memories, adult choices and shared experiences of grappling with racialised adolescent identities. As life stories narrated by mostly women and othered individuals, whose exclusion is deeply steeped in colonial history, it is not surprising to find that the subjectivities described are markedly relational and embodied, two frequent characteristics of autobiographical writing by women and by postcolonial writers (Smith and Watson 1992, 2001; Neuman 1994; Whitlock 2000, 2007; Moore-Gilbert 2009). They also foreground certain tropes and moments of crisis that constitute a repeated experience in mixed-race lives. Most of the stories in Tangled Roots explain the process of becoming the adult that the narrators now are, their childhoods spanning different decades and a broad geography of urban and (less frequently) rural environments across mostly England but also generally the United Kingdom. The child's stepping out into the world often involves encountering racial abuse, prodding curiosity about their bodies (hair, skin), and racist ideas and attitudes by teachers and total strangers. Katy Massey recalls growing up in 1970s Leeds knowing she was "half-caste" (then an accepted term), but with "a very limited notion of blackness" and being the object of commiseration, "bigotry clothed in compassion" (Massey 2015, 11). Bernardine Evaristo also evokes a then predominantly white Woolwich, being "the half-caste tribe down the street" (32) and knowing little about her Nigerian father's culture. Blackness as an identity only materialises for her at college, after meeting other black women. Subsequently, moving into the arts world, she comes face to face with the question of authenticity, the prescriptive and essentialist notion of "the Authentic Black", the accusations of not being black enough. Her final alignment is with black people across the world while embracing her multiplicity (37). Evaristo's voyage is not unlike others in the book, which move from the relative safety and normalcy of their home environment to an ever widening social world which judges and defines them on the basis of bodily 
appearance: phenotype, shade, hair, closeness to the normative white model and, more frequently in female adolescents, expectations of exoticism.

While the family home in these life stories is not necessarily free of conflict or even violence, the creation of an otherly embodied subjectivity tends to take place at secondary school, with the adoption of a chosen self and alignment happening in early adulthood. Schools are major sites of remembered crises that function as traumas, rites of passage or both. Hannah Lowe ("A Case of (Mis)identification?"), born in London to a father of Jamaican African and Chinese descent, but herself white-skinned like her mother, remembers the racist school climate in Essex, where she is a "white wog" to a fellow pupil and her teacher writes in her homework "no such word" next to a red circle around "Anglo-centric" (40-41). The fictional story contributed by Sindi F. Gordon ("Skipworth Street's Bonfire Night") includes another key school passage, when the headmaster jokes in the assembly that Highfields "is the melting pot of England or as some might say sticking pot because no one seems to be going home" (100). The reaction to this remark leads to two students being sent out of the hall: the narrator (instead of her white best friend, who murmurs a reply) and her admired and desired Nigel, who provokes the fury of the headmaster by replying "We are at home" (100). The rejection and displacement are made stronger when class issues intervene, as reported by Segun Lee-French ("How I Learned to Love Being White") growing up in 1970s Manchester: "Before the age of 11, my life was simple: I was just a kid from Hulme. My best friend in the neighbourhood was black, and my best friend at primary school was white" (137). At this multi-ethnic school, race was rarely an issue, although when insults did happen, it was made clear that he (despite his mixed heritage) was black. After receiving a scholarship to the massively white Manchester Grammar School, however, racial abuse becomes an aggressive daily occurrence. Lee-French describes his voyage from being "deracinated" and wanting to be a stockbroker, to identifying as black, "rooting for the underdog" (138), and finally, after a visit to the Nigeria of a father he never knew, learning to love being (also) white, while opposing the complex workings of white supremacy and continuing to be markedly aware of social class.

One of the younger contributors to the volume, Nadine Bates ("Life in Black and White"), describes three moments of crisis in her teenage years and their long-term consequences. Having grown up in Leeds with loving parents, a Leeds-born black mother of Caribbean background and a white, Yorkshire-looking and sounding father born in St Kitts, she embraces being "equally both" and resents the repeated pressure to choose. Her crisis episodes shake her adolescent sense of self: the first takes place when she is sixteen, working as a cashier, and is the object of premeditated racist abuse by an old 
man who considers he did not fight the war for "people like you to come over here" (72). Despite the support from staff, who ban him for life, she is shaken, as she is in her university years when shopping with a friend and a white woman proclaims loudly that she will cover her handbag, as "some types of people can't help themselves" (73). Her third story involves a fellow footballer insisting on asking her, publicly and privately, whether she would be offended to be called "nigga", the black-only reclamation of the term "nigger" controversially used in US hip-hop music. The account of this intrusive, supposedly friendly question (she suspects the girl aspired to using the word and sounding "cool"), precedes her final meditation on her current (at 26 years of age) worries about love, children and the response of families to her future love choices, together with the pain of feeling conditioned to think so.

These are but a few examples of the early building of mixed race subjectivities offered in the book, whose diversity of origins, locations and experiences, though inevitably random, is impressive. The stories allow readers an insight into the careful thought about their relational self-identity conducted over the years, for, as Massey puts it, after all, they have been asked to "explain themselves" all their lives (19). From Evaristo's second-person narrated bio-essay ("The Privilege of Being a Mixed-Race Woman") to Sarfraz Manzoor's account of becoming a parent to a mixed race child ("Qurbani"), they convey a deep awareness of personal choices and the weight of external constraints. These are peppered with tales of shared micro aggressions: name-calling, judgment of life-style, invasion of privacy, pressure to conform or to choose one heritage. The most repeated is perhaps the question which all racialised people spend their lives answering: "Where are you from?/Where are your parents from?", in the case of mixed race people with the addition of the objectifying "What are you?" (the first item on the list of internet writer Anjali Patel's "18 Things Mixed Race Girls Are Very Tired of People Saying to Them"; discussed in Boakye 2019, 39). The many variations on these in the texts show their insidious persistence. Manzoor's Scottish and British Pakistani child, Leila, asked by a total stranger, as a four-year-old, where she was born, "looked at the woman and said, as if it was the most obvious thing in the world, 'in a hospital' " $\left(5^{2}\right)$. The candid chastising reply stems from the safe world of a loving home environment, although one not totally able to screen out racism. Replying not to what but to who they are in these life stories, contributors appeal to cultural heritage, history, and to parents and siblings. Charlotte Williams ("Auntie"), holding historical memory as the committed writer she is and the "Auntie" she has become with the years, remembers the far and recent history of race relations, when there was no "brown", only black - "when was it that it became so cool to be brown?" (59) and wonders what the future consequences of relinquishing that history might 
be. The contributions add histories of Apartheid, colonialism and migration to personal accounts of love and relationships, all unique, but conditioned by a historical past to which the British majority are conveniently oblivious, as they are ignorant of the basic facts about Africa or the Caribbean. Felicity Kaal ("No Tigers in Africa"), who moved with her family to the United Kingdom from the cosmopolitan city of Cape Town and grew up in the Chilterns, reports being taunted by questions about living in the "jungle" with tigers, the myths about Africa ingrained in collective English memory.

Intrafamily relationships are inevitably affected by such exclusionary practices. Fathers are sometimes absent in these stories, except as a bodily and cultural legacy to be explored; in other narratives they are present but become a source of offspring shame. Hannah Lowe recalls explaining away her Caribbean father as a cab driver; Evaristo has also acknowledged this-fleeting — denial of a dark-skinned father who estranged her from peers (Evaristo 2008, 2-3). Shame, a relational affect which necessarily requires a witness, is related, as Sara Ahmed argues, to "the gaze of an ideal other", from whose eyes we contemplate ourselves as a failure because we fail to approximate the other's being, to produce a self that belongs to the community, a proximate "we"; shame involves desire and love: "we feel shame because we have failed to approximate an 'ideal' that has been given to us through the practices of love" (2004, 106; emphasis in the original). From this shame, this failure to see themselves as community selves, are born the confessed disowning of black/Asian parents by children in predominantly white communities, but also those of white mothers, in the face of what Ifekwunigwe (borrowing from Adrienne Rich's compulsory heterosexuality) has termed "compulsory blackness" (2002, 335). By contrast, siblings, even in stories where the narrator has the social privilege of a paler shade, tend to produce solidarity and a clear alignment with the black or ethnic side of the self-Kaal and Evaristo both speak of aligning with their darker siblings and of the street policing and aggressions towards black males. This area of intrafamily relationships, as Miri Song has pointed out, merits further comparative research $(2010,353)$. Mothers, frequently white British or Irish, have a strong presence in the collection. They provide daughters with examples of bravery and border-crossing, sometimes as single parents and, when fathers are immigrants, they smooth out the path into British social protocols, as Evaristo describes. For their part, African or Caribbean mothers mould the self because, as Diana Evans puts it in the opening story ("A Visit to My Mother"), "Your mother is your first country" (Massey 2015, 26), an embodied place of origin, who feeds you a section of your culture. Now the mother of a young child, the narrator attempts to convey this everyday heritage to her own daughter by cooking her mother's dishes, eba and stew, even if "[i]t is not eba. 
The stew is not the same orangey-red that only my mother can achieve. But it is close. It is good. It is who I am" (28).

On the whole, these texts play with life stories, sometimes explicitly so, to convey a personal memory of becoming their present selves, the sometimes tortuous path to being able to declare "I feel whole, contented with my layers, and ready for more" (Mukene-Knight, "Self Portraits", Massey 2015, 169), and "I am my own kind of black woman and my own kind of mother, with my own wonderful family" (Chérie Taylor-Battiste, "Uprooted", Massey 2015, 211). They work across genres - history, travel writing, short story, essay — as they have worked across subjectivities, to represent these complex, unique and fluid selves.

The fact that contemporary mixed race stories are the result of personal relationships, chosen and maintained against the grain (quite differently from the coercion and rape engineering mixed race births during colonialism and slavery), has been the object of illuminating research about mixed race Britain (Alibhai-Brown and Montague 1992; Alibhai-Brown 2001). Not surprisingly, it has also occupied novels by writers such a Zadie Smith, Monica Ali and Hanif Kureishi. Jackie Kay's The Adoption Papers (1991) and Red Dust Road (2011) are carefully crafted and frequently discussed explorations of her dual origins and adoption by Glaswegian parents, but Kay's short stories have been less debated in terms of this enquiry, and her deployment of racial issues is frequently downplayed, perhaps due to the succinct manner in which they enter plots. And yet, Kay's first collection of stories, Why Don't You Stop Talking? (2002) not only includes several main characters who are mixed race, and a grandmother who contemplates her mixed progeny ("The Oldest Woman in Scotland"), but in fact tackles uncomfortable issues such as that of white single mothers ("Shell") or the fates of mixed race daughters (of Irish, Scottish and English mothers: "Trout Friday", "Big Milk” and "Why Don't You Stop Talking?”). These stories pioneer an approach to a mother/daughter relationship which at the time remained unexplored, as Jayne O. Ifekwunigwe contended in Scattered Belongings (1999),, ${ }^{4}$ published shortly before Kay's collection:

4 Some attention has since been paid to the matter, see SuAndi (2019). 
One could argue that from the cradle, métisse ${ }^{5}$ women who have been mothered by White women are potentially equipped with the social tools for understanding White feminists and building coalitions across the Black/White feminist divide. Yet, amid all the feminist academic attention paid to mothering and mother/daughter relationships, very little if any textual space attends to this strategic possibility. Both Black and White feminists have also neglected the specific problematic of the biracialization of White mother/Black (metisse) daughter dyads.

IFEKWUNIGWE 1999, 173

Kay's stories meaningfully describe this mother/daughter dyad, if always as a subtext to the conflict presented in each narrative. "Big Milk" chooses a genealogical history close to the author's own: the narrator, feeling displaced from her lover's body by her two-year-old breast-feeding baby, decides impulsively to go in search of her biological Highland mother: "She will know instantly, from the colour of my skin that I am her lost daughter. Her abandoned daughter" (Kay 2002, 31). She fantasises about her alternative life if, rather than adopted after two weeks, she had been breastfed by her birth mother for two full years, therefore acquiring a different language, profession, belonging. The topic of mixed-race birth and abandonment underlies the fantasies of the narrator, who visualises herself lying "across my mother's white breast, my small brown face suffocating in the pure joy of warm, sweet milk" (29). We are left to imagine the reasons why this did not happen, as well as the encounter itself when she reaches the house, although the sour milk contained by the two bottles at her mother's door is inauspicious.

By contrast, in "Trout Friday" Melanie (of the symbolic name, meaning black/dark in Greek) has been brought up single-handedly by her Irish mother, recently deceased. The story narrates the day in which Melanie, 23, living alone, receives a letter from her estranged Trinidadian father asking to meet her. But Melanie cannot afford to disrupt her painstakingly ordered life. The fragility of her balance is revealed in her meticulous professional work as a travel agent and her over-precise planning of solitary meals for each day of the week. Inescapably aware of her colour and of imposed identities, she rejects the new term beige, Beige Britain, ${ }^{6}$ as she does half-caste, mixed-race,

5 Ifekwunigwe uses the term métisse in this book. She will explain her reasons for the change to mixed race in later texts, particularly in the section "Notes on Terminology" in Mixed Race Studies: A Reader (2004, xix).

6 "Beige Britain" had hit the headlines on 22 May 1997, when Gary Young wrote in The Guardian: "Beige Britain ... a new race is growing up. It's not black and it's not white and it's not yet officially recognized". 
mulatto, used by workmates and customers, and is uncomfortable with red and high-yellow, used by other black people to describe her (69-70). She leans on the memory of her Irish mother, who "liked being different" and after a few drinks would say, "Look at you! Aren't you beautiful? Aren't my you beautiful daughter? And don't you let anyone tell you otherwise, do you hear?" (70). Taking strength from her mother's love and the lyrics of Coldplay's 2000 hit "Yellow" ("The words were about her", 78), she sticks to her self-control and decides that her father and boyfriend can both "take a running jump" while she reinvents herself: like the wine she is savouring, "crisp, cold, elegant", or perhaps "Fruity. Buttery. Bold" (81).

Melanie's control and rationality are in contrast with the explosive Thelma in "Why Don't You Stop Talking”, incapable of shutting up before aggression, a disapproving look, or even before silence. In the form of a dramatic monologue, the story begins with a chance encounter in a London supermarket, where Thelma catches another woman looking at her shopping: "I know myself and I know other people. And I know when someone's coming over all judgemental. And she was. So I said to her, 'Life's too short to worry about having a fat arse'” (Kay 2002, 39). What follows is a description of both women's reactions to each other: embarrassment in the case of the polite, white, middle class, healthy-food-consuming woman; anger-first at the looking and then at the evasions and silences - on the part of the narrator, who insists on challenging the other shopper until she is asked the silencing question, "Why don't you stop talking?": "I had to admit she had a point there. I do have one of those tongues that gets me into a load of trouble. I can't help myself" (40-41). An only partially reliable narrator, Thelma's life is marked, in her own (genealogical) view, by her inability to keep her mouth shut:

My mother talked a lot. You couldn't get a word in with her. And she could be vicious with her tongue. I'd rather she'd hit me than have heard the half of what she said to me. My dad talked with his hands and his mouth when he was around. My dad was from Jamaica and my mum were a real East Ender. I don't see them anymore and they don't see each other. One Christmas we all said things we shouldn't and once they were said we couldn't get over them. I reckon families should be banned. They should find some other way of doing it.

KAY 2OO2, 44

Thelma has a further verbal encounter with a man who jumps the queue at the cash machine and she is later attacked by a woman who is violently scolding and shaking her two-year-old child in the street, and whom she 
addresses - politely this time - in an attempt to spare the child. In all cases, the response is aggressive and on return to her council flat she punitively cuts her tongue with a razorblade. The reader cannot but perceive the intersectional conjunction of factors that condition Thelma's life, but also the ways in which, returning to Sara Ahmed, "'being emotional' comes to be seen as characteristic of some bodies and not others". Ahmed discusses how emotions "circulate between bodies [...] how they 'stick' as well as move" (Ahmed 2004, 4). In this relational process, where contact is the necessary condition, the effects of repetition are crucial. Thelma is signalled out as emotional although the people she encounters display their own emotions; but Thelma's body is an "out-of-place" body (Ahmed 2000) because it is fat (chocolate biscuits cause and effect), it is brown (biracial), it speaks in unorthodox grammar (social class). Body weight and colour are part of the structures of power and Thelma has become one of the bodies to which a "sign" (fat, black), a predetermined emotion (anger, disgust, shame), has been stuck. The very repetition of such judgement in her life has "stuck" with her own body, making her internalise the emotion and blame herself.

While these two stories leave readers guessing at the adolescent conflicts that their adult crises reveal, "Shell" is both a story of adolescent mixed-race crisis and of middle-age single mother fatigue, focalised through the metamorphosis of a white mother, Doreen, coping with a scowling, unhappy teenage son, Louis. This wearying everyday conflict is not enacted in racial arguments, but in the antagonistic attitude displayed by the 14-year-old son and the growing, paralysing burden laid on the mother. On the day she discovers that her son pretends at school to be living with his absent father, she begins to grow a defensive shell that is "protective", "loyal", "trustworthy" (149), "a lover, a solid companion that knows and accepts her faults" $(2002,150)$. Only two significant moments refer to colour difference: one in which Doreen looks back to when he was a baby at her breast, "[t]here was no father to be seen for miles around. Just her and her baby, the light and the dark" (140); and a meaningful plea from Louis for a closer haircut: "All the black boys have short hair" (139). Dropping him off near the school, to spare his embarrassment at her car (only?), she observes his transformation into a teenager, "walking a cool black boy walk" (140). Doreen's past transracial relationship is quietly posed as a determining factor in her lonely, unhappy present in the Manchester she grew up in (also undetailed). This life is now disrupted by unemployment, a disdainful and demanding son, a cumbersome body, poverty, powerlessness. The ending, in which she retreats into her shell and moves into the garden, fully metamorphosed into a tortoise, allows her an escape from a non-life, in which not even her son acknowledges her existence as a human being. 
These stories by Jackie Kay are mostly urban, intersectional, but tend to focus on marginalised individuals and unconventional relationships. The collection contains one more passing reference to mixed-race children, in the story "The Oldest Woman in Scotland", in which the formidable character whose 107th birthday is being celebrated, contemplates her descendants assembling for a family photo:

They look a queer family anyway, all lined up on the couch for the camera. There's her youngest, her favourite daughter, Elsie, who has still got braw skin like her mother used to, there's her scruffy son-in-law, no even able to put on a proper shirt for the occasion, his hair falling in every direction; there's her overweight black granddaughter with her bonny face and her dark eyes, her long dangling earrings and her big bosom; there's the great-grandson, black as the Earl of Hell's waistcoast, with such tight, tight curls on his head and his eenty teenty English voice; and there's the great-granddaughter with her long loose black curly hair and her cheeky wee smile.

KAY 2OO2, 120

This gran is unfazed by colour, far more bothered by her great-grandson's English accent, making him sound "like Edward the eighth" (119). The strong elderly female character and the glimpse that this story offers into generational changes constitute a link to the narratives in Bernardine Evaristo's Girl, Woman, Other (2019) which we will discuss to conclude.

While liminal literary forms can be claimed for many purposes, certain authors explicitly deploy them in relation to multiple identities. In Tangled Roots, Lisa Lowe explains her recent use of a form she names "border-liner", reclaiming a term which is derogatory slang for mixed race, in order to "embrace and reinvent it, to serve those whose identities are complicated and in flux, like mine" (Massey 2015, 46). She exemplifies this by including a poem with a zig-zagging internal border, offering at least two entwined double-direction readings, across and down. For her part, Bernardine Evaristo has always challenged conventional literary form, and frequently defends experimental writing as oppositional, disruptive of expectations and counter-cultural. In multiple media interviews following the publication of Girl, Woman, Other, she defined its form-its absence of full stops or paragraphs, its free flow of sentences, 
rhythms, characters; its poetry-like disposition on the page-as "fusion fiction", allowing her an expressive freedom grounded in multiple genres. In terms of macrostructure, the novel resembles the genre of the short story cycle, as practiced, for instance, by many Canadian authors, in that its stories (here subchapters) can be read independently but are expanded and revised in other stories/subchapters, linked by characters and events. The last triptych of women portrayed in the novel-Megan/Morgan, Hattie and Grace-whose lives make up Chapter Four, are a multi-ethnic lineage descended from an English coalminer's daughter, Daisy, who in 1895, in the Northumbrian locality of South Shields, met a seaman from "Abyssinia" (Evaristo 2019, 372) and gave birth to their mixed-race daughter, Grace.

The story of this triad is told in a reverse timeline, beginning with the youngest, Megan/Morgan, who self-identifies as gender-free and asks to be referred to as they; she is the great-granddaughter of Hattie, heir and farmer of the Greenfields property, who married Slim, an African American soldier, after World War II. Hattie is herself the daughter of Grace, born of Daisy and the "Abyssinian", who marries the ginger-haired Joseph Rydendale, heir of Greenfields, on his return from The Great War. This female lineage, expanding from 1895 to the present, allows an incursion into the entanglements of imperial and global history across the twentieth century; it also refutes the popular belief that Britain was white until the Windrush generation. Evaristo's interest in black European history is long-standing, and she has acknowledged the inspiration of Langston Hughes's 1959 insight that, after travelling around the world, one learns that "there is at least one negro everywhere" (Hughes, $I$ Wonder, quoted in Evaristo, 2008, 2). Having herself learnt of the black ancestry of Dumas and Pushkin, of the existence of mixed-race children across Europe in the most unexpected circumstances (such as post-holocaust Germany), the presence of mixed-race individuals in Europe, she concludes, is endemic (2008, 5). This fact is brought to attention throughout her novel. The triptych of stories in Chapter Four places each woman in her historically specific context of racialisation, even if they are all singularly resilient to its pressure, enacting a decided refusal to conform. Their strength, which the young Daisy inaugurates by refusing to give up her child for adoption, is a denial of racial shame: "Don't you ever be ashamed of where [your father] is from", the young Daisy admonishes her child (Evaristo 2019, 377). And Grace never is. She proudly acknowledges her "Abyssinian" father in the home for girls where she grows up, following her mother's early death from tuberculosis, and where semi-enlightened (white) proto-feminists train her to be a servant, but warn: "you have too much personality [...] too much personality is unseemly in a girl" (381); Grace will later make sure that the powerful boyish personality of her own daughter, 
Hattie, is not thwarted; and Megan/Morgan, two generations down the line, leaves home to construct her own queer life against the grain of family desires.

Patriarchal power is a crucial intersectional factor in the novel, and is shown to die hard. The fatherly shame ("a half caste / Daisy's father said he'd never live the shame down at the pub", 373) that forces Daisy to choose between her family and Grace, painfully reappears in Grace's own husband, who arranges the adoption of the illegitimate child of their own fourteen-year-old daughter, Hattie. This pattern of abandonment and adoption, too common in cases of mixed-race children, is contrasted in the novel with the secret lineages traced through colonial ancestry. Captain Linnaeus Rydendale, founder of Greenfields farm, returns from Jamaica with a young wife, Eudoré, whose portrait reveals her to be black, despite family legend making her Spanish. This fact is unravelled by Slim's trained black American eye ("she's one of us, Hattie", 367 ), an instinct which also leads him to examine the secret family documents proving the Captain to have been a slave runner. A terrible uncovering, but as Hattie reasons, they now own "the spoils", so "it's come full circle, hasn't it?" (368).

The stories of Daisy, Grace and Hattie, corresponding to the first part of the twentieth century, are detailed social portraits of the turn of the century and the two post-war eras, with the specificity of race-relations that span from the height of the British Empire to its relative loss of power to the United States following the Second World War. For Daisy's generation of poverty-stricken adolescents (at a time when the concept of "adolescence" was yet to be invented), the seamen reaching their towns were an embodied hope of being transported to "magical places with names like Zanzibar, Casablanca, Tanganyka, Ocho Rios and South Carolina" (373). In post wwi England, Grace's eventual husband, John Rydendale, is able to appreciate her features because he has fought in Egypt and known the "Ottoman beauties of the Orient" (388). Yet despite the family history of Jamaican spouses and slavery, he must wait for his father to die before marrying his "lady of the Nile" (386) who might give him a coveted heir. In the next generation, their daughter Hattie will consider herself unmarriageable, as her mother had done before her; she will meet her husband, in classic post-war style, at a Newcastle dance for demobbed African Americans, where black women gather from towns across Britain. Hattie is charmed by his respectful manners, Slim admires her "creamy" complexion (362) and will never return to the United States, where his 15-year-old brother had been lynched.

Despite the strength of so many characters, Girl, Woman, Other underlines the fragility and contingency of alliances and identifications. Slim's political consciousness as a black person, ahead of its time in the United Kingdom, will not survive in Sonny and Ada Mae, who reject their heritage and rural 
origins, escape to sixties London as teenagers and eventually return to urban life in Newcastle, performing unhealthy jobs and marrying white partners. When next-generation Julie, Megan/Morgan's mother, marries a hospital co-worker from Malawi in the 199os, her siblings reject him as the embodiment of a "backsliding" in the family progress towards whiteness (350). The intersectional social pressures exerted on the self-esteem of Sonny and Ada Mae are only hinted at (class, the urban/rural divide, generational conflict), but it is striking that the supposedly liberal sixties result in such denials, compared to the firmly held pride of Victorian Daisy. Hattie has to skip two generations in her search for a deserving heir for her farm: she leaves it to her great-granddaughter Megan/Morgan, who shows the fighting spirit and love for nature that Hattie's closer descendants lack.

Megan/Morgan is one of the faces of the complex twenty-first-century Britain: born in the 199os, "part Ethiopian, part African-American, part Malawian and part English / which felt weird when you broke it down like that because essentially she was just a complete human being" (311). Her great-grandmother Hattie is the only relative to accept her as she is, in contrast with her mother's expectations of Barbie cuteness, sought "as validation of her love for an African man" (308). And while, in the spirit of the new century's fetishisation of mixed race girls, her classmates admire "her blonde corkscrew curls" and "natural suntan" (312), at 16, Megan shaves her hair, begins to wear men's clothes, is shunned by former friends and leaves school, embarking in the ups and downs of trying "to reach the core of herself" (317). She eventually does after discovering feminism and Bibi, an Asian trans woman who becomes her partner. When we meet Morgan (no longer Megan), she has become an "influencer" with a twitter following of over a million, reviewing the National Theatre play that opens and closes the novel. The connection between Hattie, born in the 1920s, and this hyper-contemporary descendant stems from an affinity of character but also suggests the power of coalition politics, a recognition of the outsider position occupied by both; this intuition is confirmed when Hattie recalls her mother being first welcomed in the all-white town by an undeclared lesbian couple.

Evaristo's novel interweaves many lives inspired in the hidden history of Britain. The interconnectedness of characters and events, while appealing to biological genealogies, is better explained through the structure of knowledge proposed by Gilles Deleuze and Felix Guattari (1980), whereby epistemology and description do not follow hierarchical tree structures but the rhizomatic pattern in which any one element can affect all others. In the epilogue of Evaristo's novel, we are offered one final example of linked destinies, brought about by a search into Hattie's DNA ancestry. Morgan begins this search when 
Hattie confides the wish to track down her "Abyssinian" grandfather. The search, however, leads instead to the location of Hattie's lost child. A character previously met in the novel, this woman's world is shaken by the discovery, but she decides to meet Hattie, the reunion rounding another micro-historical circle.

In Scattered Belongings (1999), after noting the lack of research on the white mother/black daughter dyad (as quoted above), Jayne O. Ifekwunigwe reflects that "[p]erhaps, like many theoretical innovations, this critical issue must begin its life on the pages of (auto)biographies or in the creative arts" (173). The biographical and fictional texts discussed here seem to indicate that they run parallel to, and often anticipate, critical theory. Recent mixed race studies have identified a movement towards a subjectivity of liminality, an awareness of shared multiplicity which does not occur in binary terms nor in terms of abstract hybridity (Daniel, Kina, Dariotis and Fojas 2014), but rather in forms closer to Deleuze and Guattari's rhizomatic, additive structure, a pattern which underlies Jayne Ifekwunigwe's proposal of the ampersand paradigm, further defined by intersectionality. The texts which we have discussed suggest some measure of shared awareness while underlining the workings of intersectional factors found to be crucial in the case studies analysed by critical theorists and sociologists (Ifekwunigwe 2002; Song 2010). Tangled Roots, by collecting the life stories of a varied sample of mixed-race British individuals, is able to deny the myth of homogeneity and to highlight the importance of class, generation, location, among other factors; but simultaneously, in the very act of bringing authors together, it creates an expectation of shared experiences, a number of which are indeed verified by the stories, particularly those born of growing among exclusionary (white) practices and the construction of multiple-heritage, fluid selves.

The texts reveal the persistence of racialisation and exclusion, but they also indicate that the tension between national racialised constructions and individual subjectivities has been relaxed in recent decades, enabling a freer creation of identities that may counteract the recurring trope of young racialised shame. The cumulative effect of stories which construct a confident multiracial identity, one that can strategically identify with the racialised group without denying further identifications (an additive rather than compulsory blackness, in Ifekwunigwe's terms), supports a future of more fluidly constructed selves and political coalitions that go beyond the binaries which sustain 
monoethnicity. This expanded corpus of stories which foreground mixed race women provide recognition and visibility, as Massey and Evaristo report of the feedback to their books. Their narratives inscribe the ubiquity of mixed race in British history and territory, the presence of individuals who add a transnational, cosmopolitan component to Britishness compatible with avowed locality. The 2021 census may offer a new map of identifications; and the contingency of political motivation in times of globality may also transform self-definitions. It is too soon to assess the inflections which may be added by Brexit and the growth of the Black Lives Matter movement, happening as this chapter is revised amid the also unpredictable covid-19 crisis. Hopefully, the added effect of these and other multi-heritage stories will continue to construct a more inclusive, less insular, conception of Britishness and to add depth to the understanding of difference and to the history of human lives.

\section{Works Cited}

Ahmed, Sara. 200o. Strange Encounters. Embodied Others in Postcoloniality. London and New York: Routledge.

Ahmed, Sara. 2004. The Cultural Politics of Emotion. London and New York: Routledge. Alibhai-Brown, Yasmin. 2001. Mixed Feelings: The Complex Lives of Mixed-Race Britons, London: The Women's Press.

Alibhai-Brown, Yasmin and Anne Montague. 1992. The Colour of Love: Mixed Race Relationships. Virago.

ввс. 2011. "Mixed Race UK Population Double Official Figure, Says New Report".

6 October 2011. https://www.bbc.com/news/av/uk-15205803/mixed-race-u k-population-double-official-figure-says-new-report.

Boakye, Jeffrey. 2019. Black, Listed. London: Dialogue Books.

British Future. 2011. The Melting Pot Generation. http://www.britishfuture.org/ wp-content/uploads/2012/12/The-melting-pot-generation.pdf.

Caballero, Chamion and Peter J. Aspinall. 2018. Mixed Race Britain in the Twentieth Century. London: Palgrave Macmillan.

Daniel, G. Reginald, Laura Kina, Wei Ming Dariotis and Camilla Fojas. 2014. "Emerging Paradigms in Critical Mixed Race Studies." Journal of Critical Mixed Race Studies 1 (1): 6-65, https://escholarship.org/uc/item/2db5652b.

Deleuze, Gilles and Felix Guattari. [1980] 2004. Capitalisme et Schizophrénie 2. Mille Plateaux. Paris: Minuit (A Thousand Plateaus: Capitalism and Schizophrenia, translated by Biran Massumi. New York: Continuum.

Evaristo, Bernardine. 2008. "CSI Europe. African Trace Elements, Fragments. Reconstruction. Case Histories. Motive. Personal." Wasafiri 56 (Winter): 2-7. 
Evaristo, Bernardine. 2019. Girl, Woman, Other. London: Hamish Hamilton.

Hirsch, Afua. 2018. Brit(ish). On Race, Identity and Belonging. London: Jonathan Cape. Hussein, Sofaya. 2015. “'Mixed Girls' on Social Media." MA Dissertation. Oviedo 2015. Ifekwunigwe, Jayne O. 1999. Scattered Belongings. Cultural Paradoxes of "Race", Nation and Gender. London: Routledge.

Ifekwunigwe, Jayne O. 2002. "(An)Other English City. Multiethnicities, (Post)modern Moments and Strategic Identifications." Ethnicities 2 (3): 321-348.

Ifekwunigwe, Jayne O. ed. 2004. "Mixed Race” Studies: A Reader. London: Routledge.

Kay, Jackie. 1991: The Adoption Papers. Newcastle on Tyne: Bloodaxe.

Kay, Jackie. 2002. Why Don't You Stop Talking? London: Picador.

Kay, Jackie. 2010. Red Dust Road. London: Picador.

Massey, Katy, ed. 2015. Tangled Roots: True Life Stories about Mixed Race Britain. London: Biddles.

Neuman,Shirley.1994. “'Anappearancewalkinginaforest the sexes burn':Autobiography and the Construction of the Feminine Body." Autobiography and Postmodernism, edited by Kathleen Ashley, Leigh Gilmore and Gerald Peters, 293-315. Amherst MA: University of Massachusetts Press.

Moore-Gilbert, Bart. 2009. Postcolonial Life-Writing: Culture, Politics and Self-Representation. London: Routledge.

Patel Anjali. 2015. "18 Things Mixed Race Girls Are Very Tired of People Saying to Them." Bustle, March 18, 2015, https://www.bustle.com/articles/70567-18-things-mixed-r ace-girls-are-very-tired-of-people-saying-to-them.

Smith, Sidonie and Julia Watson, eds. 1992. De/Colonizing the Subject: The politics of Gender in Women's Autobiography. Minneapolis: University of Minnesota Press.

Smith, Sidonie and Julia Watson. 2001. Reading Autobiography: A Guide for Interpreting Life Narratives. Minneapolis: University of Minnesota Press.

Song, Miri. 2010. "Is there 'a' Mixed Race Group in Britain? The Diversity of Multiracial Identification and Experience." Critical Social Policy, 30 (3): 337-58.

$\mathrm{Su}$, Andi. 2019. Strength of Our Mothers. Manchester: artBlacklive.

Whitlock, Gillian. 2000. The Intimate Empire. Reading Women's Autobiography. London: Casell.

Whitlock, Gillian. 2007. Soft Weapons: Autobiography in Transit. Chicago: Chicago University Press.

Young, Gary. 1997. "Beige Britain.” The Guardian. 22 May 1997 (G2, front page). 